\title{
Obesity and Overweight Problem in Children (7-12 years) Coming from Affluent Families in Dhaka city in Bangladesh
}

\author{
Sanjoy Saha ${ }^{1}$, Md. Khurshidul Zahid ${ }^{1 *}$, Sabrina Rasheed ${ }^{2}$ \\ Institute of Nutrition and Food Science, University of Dhaka ${ }^{1}$ \\ Social and Behavioral Sciences Unit, ICDDR,B, Dhaka ${ }^{2}$
}

\begin{abstract}
:
The study find-out the obesity and overweight problems in children (7-12 yrs) coming from affluent families in Dhaka city in Bangladesh. Mean height and weight were $142.61 \pm 10.43 \mathrm{~cm}$ and $40.50 \pm 11.95 \mathrm{~kg}$ respectively. One fourth (25\%) of the students were found to be obese and $21.88 \%$ were overweight according to their BMI percentile. Among boys 31.43\% were obese and for the girls it was 7.69\%. Among boys $18.57 \%$ are overweight and for the girls it was $30.76 \%$. Male students were both obese and overweight than the female. Most (63.64\%) of the male obese students were in the age group of 7.92-9.17 yrs and 10.5-11.67 yrs where as most (62.5\%), $n=5$ of 8 ) of the female obese students were in the age group of 7.92-10.42yrs. Based on WAZ, $12.5 \%$ of the students were found to be obese and $10.41 \%$ were overweight. Among boys $28.34 \%$ are obese and for the girls it was $6.82 \%$. Among boys $25.71 \%$ are overweight and for the girls it was $35.23 \%$. Male students are more obese than the female. Based on HAZ One sixth (5.20\%) of the students were found to be obese and $17.70 \%$ were overweight. Among boys $28.34 \%$ are obese and for the girls it was $6.82 \%$. Among boys $25.71 \%$ are overweight and for the girls it was 35.23\%. Based on WHZ one sixth (4.23\%) of the students were found to be obese and $8.51 \%$ were overweight. Among boys $28.34 \%$ are obese and for the girls it was $6.82 \%$. Among boys $25.71 \%$ are overweight and for the girls it was $35.23 \%$. Male students are more obese than the female.
\end{abstract}

Key Words: Obesity and Overweight, BMI Percentiles, WAZ,HAZ, WHZ.

Bangladesh Journal of Nutrition. Vol. 24-25 December, 2011-2012. Institute of Nutrition and Food Science, University of Dhaka, Dhaka-1000, Bangladesh.

* Author for Correspondence 


\section{Introduction:}

Under nutrition is one of the most important problems in developing countries. Now a day's prevalence of over-nutrition (overweight and obesity) in children coming from affluent societies of developing countries is increasing rapidly. Over-nutrition and undernutrition together is a double burden for the developing countries like Bangladesh. The magnitude of overweight and obesity is a global public health problem (WHO, 2005); as there has been an upward trend in the prevalence of obesity both in developed and developing countries. Bangladesh, a country with a large economic burden due to under nutrition, now has to deal with over nutrition as well. Childhood overweight and obesity is a condition where excess body fat negatively affects a child's health or wellbeing. So, it is very much essential to know the prevalence of overweight and obesity among children. Obesity has become an increasing public health problem internationally (1). Obesity is defined as a condition of excess body fat and is associated with a large number of debilitating and life threading disorders such as type 2 diabetes, cardiovascular disease, hypertension and stroke, and certain forms of cancer $(2,3)$. Over weight and obesity therefore, are of significant public health concerns. Excess body weight is a result of an imbalance between energy intake and energy expenditure (4). In recent years the increasing incidence of child obesity has caused concern (3). Childhood obesity has emerged as a critical health problem of the $21^{\text {st }}$ century. The most prevalent immediate consequence for obese children is social isolation and peer problem. The most important consequence of childhood overweight and obesity is a greater risk of obesity in adulthood (5). Health consequence of childhood obesity includes conditions such as hyperlipidemia, higher concentration of liver enzymes, hypertension and abnormal glucose tolerance (6). Bangladesh faces a double burden of both of malnutrition with chronic energy malnutrition (CED) remaining the dominant nutritional phenotype (7). It is important therefore, to assess the situation of the school age children.

\section{Materials and Methods:}

This research had been conducted in Dhaka city at three different English medium schools which had children of 7 to 12 years. These schools were representative of the affluent society. At first, we listed schools based on their tuition fees, location and willingness to participate in the study. Three schools were chosen based on the following criteria: availability of cafeteria, vending machines, and fast food shops in or near the school.

Study Design: Cross-sectional.

\section{Development of Questionnaire:}

A standard questionnaire was developed for collecting data on anthropometry (Height, and weight). 


\section{Collection of data:}

After attaining consents from school authority and parents, we were going to collect data from these three schools on three different specific days. These three schools provided 96 students (Male-70, Female-26) to participate in this study.

\section{Anthropometric Measurements:}

Children's weight and height were measured according to standardized procedure using appropriate device.

\section{Data analysis:}

Data was analyzed by Epi-info-6, Anthor-I , dbase-III and SPSS-12 software. Epi-info software was used to organize and analyze anthropometric data. Antho-I and dbase-III was used to analyze Z-scores. SPSS-12 software was used to organize, analyze and statistical analysis of the quantative and qualative data.

\section{Results:}

\section{Anthropometry}

Table-1: Students of different age groups involved in the study.

\begin{tabular}{|c|c|c|}
\hline \multirow{2}{*}{ Age (months) } & \multicolumn{2}{|c|}{ Students (96) } \\
\cline { 2 - 3 } & Male (70) & Female (26) \\
\hline$>95$ & 2 & 1 \\
\hline $95-110$ & 20 & 10 \\
\hline $111-125$ & 18 & 15 \\
\hline $126-140$ & 22 & 0 \\
\hline$>140$ & 8 & 0 \\
\hline
\end{tabular}

Graph -1: Students of different gender

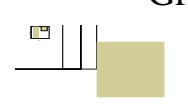


Bangladesh J. Nutr. Vol. 24-25 Dec 2011-2012

Table-2: Data on Height and weight.

\begin{tabular}{|c|c|c|c|}
\hline Index & Minimum & Maximum & Mean \pm SD \\
\hline Height $(\mathrm{cm})$ & 126.5 & 167 & $142.61 \pm 10.43$ \\
\hline Weight $(\mathrm{kg})$ & 21.1 & 68 & $40.50 \pm 11.95$ \\
\hline
\end{tabular}

Table-2 shows that mean height and weight are $142.61 \pm 10.43 \mathrm{~cm}$ and $40.50 \pm 11.95 \mathrm{~kg}$.

Table-3: Nutritional Status of Children.

\begin{tabular}{|l|c|c|c|c|}
\hline \multicolumn{2}{|c|}{ BMI for age } & \multicolumn{3}{c|}{ Number of children assessed } \\
\cline { 3 - 5 } & & Boys & Girls & Total \\
\cline { 3 - 5 } \multicolumn{2}{|c|}{} & $\%(\mathbf{n = 7 0 )}$ & $\%(\mathbf{n = 2 6})$ & $\%(\mathbf{n = 9 6 )}$ \\
\hline Underweight & $<5^{\text {th }}$ percentile & $4.29(3)$ & $7.69(2)$ & $5.21(5)$ \\
\hline Normal & $5^{\text {th }}-85^{\text {th }}$ percentile & $45.7(32)$ & $53.85(14)$ & $47.92(46)$ \\
\hline Overweight & $85-95^{\text {th }}$ percentile & $18.57(13)$ & $30.76(8)$ & $21.88(21)$ \\
\hline Obese & $>95^{\text {th }}$ percentile & $31.43(22)$ & $7.69(2)$ & $25(24)$ \\
\hline
\end{tabular}

Table- 3 shows that $21.88 \%$ of the students is overweight. Among them $18.57 \%$ are boys and $11.43 \%$ are girls. It shows that $25 \%$ of the students are obese. Among them $31.43 \%$ are boys and $7.69 \%$ are girls.

Table-4: Obesity in different age group.

\begin{tabular}{|c|c|c|}
\hline \multirow[t]{2}{*}{ Age(months) } & \multicolumn{2}{|c|}{$\begin{array}{l}\text { Obese Students(male and female) } \\
\qquad 25 \%(24), n=96\end{array}$} \\
\hline & Male $31.43 \%(22), n=70$ & Female $7.69 \%(2), n=26$ \\
\hline$>95$ & $1.43(1)$ & 0 \\
\hline $95-110$ & $10.00(7)$ & $3.85(1)$ \\
\hline $111-125$ & 4.29(3) & $3.85(1)$ \\
\hline $126-140$ & $10.00(7)$ & 0 \\
\hline$>140$ & $5.71(4)$ & 0 \\
\hline
\end{tabular}

Table 4 shows that most male students of 95-110 and 126-140 month obese whereas female students of 95-125 month old are obese. 
Table-5: Overweight and obesity in different age group.

\begin{tabular}{|c|c|c|}
\hline \multirow[b]{2}{*}{ Age(months) } & \multicolumn{2}{|c|}{$\begin{array}{l}\text { Overweight Students(Male and female) } \\
\qquad 21.88 \%(21), n=96\end{array}$} \\
\hline & Male $18.57 \%(13), n=70$ & Female $30.77 \%(8), n=26$ \\
\hline$>95$ & 0 & $7.69(2)$ \\
\hline $95-110$ & $2.86(2)$ & $19.23(5)(6)$ \\
\hline $111-125$ & $4.3(3)$ & 0 \\
\hline $126-140$ & $10.00(7)$ & 0 \\
\hline$>140$ & $1.43(1)$ & 0 \\
\hline
\end{tabular}

Table 5 shows that most male students of 126-140 months old are overweight whereas female students of 95-110 months old are overweight.

Table-6: Nutritional status based on Z-score.

\begin{tabular}{|c|c|c|c|}
\hline Nutritional Status & WAZ & HAZ & WHZ \\
\hline Under weight & 2.08 & 0 & 4.23 \\
\hline Normal & 75 & 77.08 & 82.98 \\
\hline Over weight & 10.41 & 17.70 & 8.51 \\
\hline Obese & 12.5 & 5.20 & 4.23 \\
\hline
\end{tabular}

Table -6 shows that $10.41 \%$ students are overweight and $12.5 \%$ students are obese while we consider weight for age z-score. $17.70 \%$ students are overweight and $5.20 \%$ students are obese while we consider height for age z-score. $8.51 \%$ students are overweight and $4.23 \%$ students are obese while we consider weight for height z-score.

Table-7: Summary of nutritional status through different methods.

\begin{tabular}{|c|c|c|c|c|}
\hline \multirow{2}{*}{$\begin{array}{c}\text { Nutritional } \\
\text { status }\end{array}$} & BMI percentile & WAZ & HAZ & WHZ \\
\cline { 2 - 5 } & 5.21 & 2.08 & 0 & 4.23 \\
\hline Under weight & 47.92 & 75.00 & 77.08 & 82.98 \\
\hline Normal & 21.88 & 10.41 & 17.70 & 8.51 \\
\hline Over weight & 25.00 & 12.50 & 5.20 & 4.23 \\
\hline Obese & & & & \\
\hline
\end{tabular}




\section{Discussion:}

The present study presented childhood overweight and obesity problems in affluent societies of Dhaka city in Bangladesh. Students of class- 2, 3 and 4 are assessed in this study. We found mean height and weight are $142.61 \pm 10.43 \mathrm{~cm}$ and $40.50 \pm 11.95 \mathrm{~kg}$. One fourth (25\%) of the students were found to be obese and $22 \%$ were overweight by their BMI percentile score. Among boys $31.43 \%$ are obese and for the girls it was $7.69 \%$. Among boys $18.57 \%$ are overweight and for the girls it was $11.43 \%$. Male students are more obese and overweight than the female. While we considered age in this study, we found that most male students of 95-110 and 126-140 months obese whereas female students of 95-125 month old are obese. We also found that most male students of 126-140 months old are overweight whereas female students of 95-110 months old are overweight. $10.41 \%$ students are overweight and $12.5 \%$ students are obese while we consider weight for age z-score. $17.70 \%$ students are overweight and $5.20 \%$ students are obese while we consider height for age z-score. $8.51 \%$ students are overweight and $4.23 \%$ students are obese while we consider weight for height z-score. From these (BMI Percentile and Zscores) findings it is vivid that half of the children are vulnerable to over-nutrition problems. Among them male students are in a risky position relative to female student. So, we should aware of both groups particularly for male students to reduce obesity and overweight problems.

\section{References:}

1. Wen-Harn Pan, Katherine M Flegal, Hsing-Yichang, et al. Body mass index and obesity-related metabolic disorders in Taiwanese and US whites and blacks: implication for definitions of overweight and obesity for Asians. The American Journal of Clinical Nutrition 2004; 79:31-39.

2. besity,www.who.int/dietphysicalactivity/ publications/facts/obesity/en.

3. Obesity and overweight , www.who.int/dietphysicalactivity/media/en/gsfs_obesity.pdf.

4. John M Jakicic, Amy D Otto. Physical activity considerations for the treatment and prevention of obesity. The American Journal of Clinical Nutrition 2005; 82(suppl):226S-226S.

5. H. Mozaflari, B.Nabaei. Obesity and related risk factors. Indian Journal of Pediatrics 2007; 74: 265-267.

6. Judith E. Brown,Janet Sugarman Isaacs, Maureen A.Murtaugh et al. $2^{\text {nd }}$ edition. Nutrition throughout life cycle. United States. Thomson Wadsworth; 2005:269-306.

7. Sohana Shafique, Nasima Akhter, Gudrun Stallkamp, Saskia de Pee, Dora Panagides. Trends of under- and overweight among rural and urban poor women indicate the double burden of malnutrion in Bangladesh. International Journal of Epidemiology.2007. 